THE STRUCTURE AND DEVELOPMENT OF THE SPOROPHYLLS AND SPORANGIA OF ISOETES.

CONTRIBUTIONS FROM THE HULL BOTANICAL LABORATORY. XVIII.

R. WILSON SMITH.

(WITH PLATES XIII-XX)

(Concluded from page 258)

THE SUCCESSION OF SPOROPHYLLS.

THE order of succession of the sporophylls is subject to some variation. It is not at all uncommon, especially in I. Engelmanni, to find the regular sequence interrupted by the occurrence of several megasporophylls among the microsporophylls. Occasionally, also, sporangia are found containing both megaspores and microspores. This is rarely the case in wild plants, though quite common, along with other irregularities, in those cultivated in the laboratory. Some plants taken in December, after growing rapidly for seven or eight months in the laboratory, had formed only megasporangia; some others, though producing a few microsporophylls, had failed to bring any microspores to perfection.

The sterile leaves of $I$. echinospora differ from the fertile ones chiefly in their smaller size, the reduction of the sheathing base, and the absence of a developed sporangium. They remain green throughout the winter; while the sporophylls, set free by decay of the base and buoyed up by the gas within the numerous air cavities, are borne away by currents or waves. A close study of the sterile leaves almost always reveals the presence of aborted sporangia. These range in size from a few to many hundred cells; they are often of irregular shape and have lost their protoplasmic contents, though now and then one is found in which a few spores have matured. A longitudinal section of a typical sterile leaf is shown in fig. 62, in which the shaded part I900] 
represents the undeveloped sporangium. The sterilization of the sporangium does not affect the development of the velum, a fact which supports Hofmeister's view of the primary separation of velum and sporangium. The occurrence of aborted sporangia on so many of the sterile leaves shows that all the leaves are potentially sporophylls, and suggests the probability that Isoetes has retained a more primitive form of the sporophyte than any other vascular plant.

\section{HOMOLOGY OF THE ARCHESPORIUM.}

The term "archesporium" was first employed by Goebel (I), who defined it as a cell, cell-row, or cell-plate, from which all the spore-producing cells are formed, and who concluded that in all sporangia the archesporium occupies a hypodermal position. Allusion has been made to the difficulty of accepting this conclusion in such a case as that of Isoetes, but the difficulty is not peculiar to Isoetes. Bower has shown that in several pteridophytes (Selaginella, Equisetum, Lycopodium) the archesporium is not delimited by the first periclinals of the outer layer. How shall we define the archesporium in cases where there is no single hypodermal layer from which the whole mass of sporogenous tissue is derived, and to which the term can be correctly applied as required by etymology and definition? We must either modify our conception of the archesporium or abandon the term altogether as failing to express the facts. It appears to the writer that by changing our notion of the necessary position of an archesporium we could not only avoid this difficulty but would also be enabled to make a more consistent comparison of the sporangia of seed-plants and pteridophytes than is possible with the present nomenclature.

It is pretty generally recognized that there is no true epidermis in pteridophytes. The so-called epidermis is physiologically but not morphologically equivalent to that of seed-plants, for a true epidermis is traceable to a primary layer of the embryo, the dermatogen, which is distinctly present only in seed-plants. As the dermatogen is not represented in pteridophytes, unless it 
be in the root-tip, there is consequently no true epidermis, and the part which performs the functions of an epidermis is the outermost layer of the periblem derivatives. Thus, while spermatophytes have three embryonic tissue regions, the plerome, the periblem, and the dermatogen, pteridophytes, with the possible exception of the root-tip, have only the two first-named regions.

The archesporium of all spermatophytes is hypodermal. In no case is it known to be derived from the superficial cells. The epidermis is from the beginning distinct from the inner cells of the sporangium. Though there may be periclinal divisions in the superficial cells, as in gymnosperms, many Ranunculaceæ, etc., these occur only after the differentiation of the archesporium, and the cells so added merely increase the thickness of the wall or apex of the sporangium, but never become part of the sporogenous complex. The true epidermis, set apart at a very. early period from the inner tissue of the embryo, is incapable of producing spore-forming cells. That rôle is played by special cells of the outer layer of the periblem.

It is otherwise with the "hypodermal archesporium" of pteridophytes. This is cut off by periclinal divisions from a superficial cell in the case of ferns and Equisetum, and from a group of such cells in the case of the Lycopodiales and Isoetes.

But if the absence of a true epidermis in pteridophytes and the homology of periblem with periblem in all vascular plants are conceded, then the hypodermal cells of spermatophytes are comparable, not to the hypodermal cells of pteridophytes, but to the superficial cells. As we have seen, the sporogenous mass in pteridophytes can always be traced to superficial cells, but in spermatophytes to hypodermal cells and no further; that is, in all cases the function of giving rise to spore-producing cells is localized in certain cells of the outer layer of the periblem.

These facts serve to show the inconsistency of undertaking to limit the archesporium to a hypodermal position in all cases. The cell or group of cells whether superficial or hypodermal, to which in a last analysis all the sporogenous portion of a sporangium can be traced, ought to be called the archesporium. The 
change of nomenclature which I would propose, therefore, refers only to the position of the archesporium, and not at all to the meaning of the term. It is simply this: let the term archesporium continue to be used as at present in descriptions of seedplants, but let it be understood in the case of pteridophytes to signify the superficial cell or cells from which the spore-forming tissue is derived. In this way the difficulties which have been pointed out will all be met, and a better system of homologies can be made for sporangia in general. The archesporium will always occupy the same position relative to the primary meristematic regions, and will be the only part from which the sporeforming tissue arises.

The nomenclature here proposed can be more easily understood by reference to the accompanying diagrams. Figs. 69 and 70 represent two early stages of the sporangium of a common fern (Pteris), but for the present purpose may be taken as typical of any pteridophyte sporangium. The shaded cell $(a)$ would be regarded as the archesporium; it divides into an inner fertile cell $(f)$, from which all the spore mother cells are derived, and an outer cell $(s)$ which gives rise to a large part of the sporangium wall. In some instances, as we have seen, the separation into fertile and sterile cells is not accomplished by the first division. In such cases there is no contradiction of terms, since all the spores arise from the archesporium. The final condition is the same in all cases, the difference consisting simply in the earlier or later sterilization of the wall region.

Fig. $7 I$ represents a young microsporangium and fig. 73 a young megasporangium of an angiosperm. The outer layer $(e)$, the epidermis, takes no part in the formation of the spore producing cells; $a$ is the archesporium, which usually, as in pteridophytes, divides into an outer sterile region $(s)$ called the primary tapetum, and an inner fertile region $(f)$ called the primary sporogenous cell or cells (figs. 72,74). The name primary tapetum was given to the sterile region to express its supposed function of giving origin to the true or functional tapetum. Enough is now known of the origin of the true tapetum to enable us to say 
it has no definite relation to the primary tapetum, and that in fact the term "primary tapetum" is a misnomer. The true tapetum, in many cases at least, is not represented by any morphological structure in the young sporangium.

Is it not possible that the cells $s s$ of figs. 72,74 represent the wall layer of $f g .70$, and that the "primary tapetum," in addition to the protective and sometimes nutritive purpose which its derivatives subserve, has also a phylogenetic meaning as a survival of the pteridophyte sporangium wall which has been in great part replaced by the true epidermis? Such at least is the view suggested by a comparison of embryonic organs in general, and of the relations of the primary sporogenous cells.

\section{RELATIONS OF THE VELUM.}

On the question whether the velum has any homologue among other plant structures my observations do not furnish any information. It has been compared on the one hand with the indusium of ferns, and on the other hand with the integument of an ovule. The possibility of the latter relation certainly has not been disproved, but the evidence for it is so scant that it must remain merely an interesting suggestion. As to the other relationship, it ought to be borne in mind that the only ferns which can be at all closely related to Isoetes are the eusporangiate families, and all of these bear naked sporangia. The indusium appears in fact to be a special organ of the higher leptosporangiate ferns, without representation in the lower families, such as the Osmundaceæ or in the eusporangiates. This absence of an indusium in the intermediate orders, and the doubtfulness of the homology of the various outgrowths known as indusia, make it impossible to regard the velum and indusium as more than homoplastic structures.

THE AFFINITIES OF ISOETES.

The systematic position of Isoetes has been discussed again gams, where most later taxonomists have been content to leave it.
During the first half of the present century it was most frequently 
grouped with the Marsiliaceæ and Salviniaceæ, chiefly on the grounds of their heterospory and hydrophytic habit. DeCandolle was the first to suggest a connection with Lycopodium. In this view he was followed by Brogniart, Endlicher, Hofmeister, and the later German botanists. A summary of the various relationships which have been assigned to Isoetes was given in I 888 by Vines (I), who in the same article put forth the opinion that its affinities are with the eusporangiate ferns, rather than with the Lycopodiales. More recently Farmer (I) and Campbell (4) have expressed their concurrence with this disposition of the genus.

Since this classification has been retained by Vines in his Text-Book of Botany, and adopted by Campbell in his Mosses and Ferns, it will not be unprofitable to re-examine the evidence, with the purpose of seeing what light can be thrown upon the subject by the present and other recent investigations.

In any discussion of relationships, and especially when there is so great diversity of opinion as in the present case, the conclusion is likely to be a personal one merely, dependent on the kind of evidence which the examiner holds most weighty, rather than on its absolute nature. There are some general principles, however, to which everyone will probably assent, and which ought to govern one in estimating the relative value of the conflicting evidence on which the taxonomist relies. In the first place, the larger the number of characters in which there is agreement, the closer is the relationship, especially if the characters are such as are known to have great taxonomic value in groups related to the one under consideration. Of single characters, those which are most constant are of most value, even though we are not able to detect their special utility. It is generally accepted, too, that those characters which appear in the embryonic stages of an organism serve best to mark its wider relationships, as of class or family, while characters which do not display themselves till later in the individual life are better adapted to distinguish the near relationships of species and genus. This principle applies not merely to the organism 
as a whole, but quite as fully to the embryonic stages of its different organs, such as leaf, root, sporangium, and the like.

In conformity with these principles it is proper, in the determination of natural affinities, to place great emphasis upon the reproductive parts, for such parts are found to show very great constancy in their form and occurrence. The sporangia especially, and the form and arrangement of the sporophylls, have long been recognized as of the highest importance. Thus, the classification of the Filicales is largely based on sporangial characters; and the position of the Salviniaceæ and Marsiliaceæ, which was formerly as unsettled as that of Isoetes, was established beyond doubt as soon as the development of the sporangia was fully understood.

It is chiefly on the basis of the superficial resemblances of the sporangia of Isoetes with those of Lycopodium and Selaginella that it has been so long associated with them. If we enumerate the chief differences between the sporangia of Lycopodiales and of ferns, we shall see that in every particular Isoetes agrees with the former. While the Filicales bear numerous sporangia on the dorsal surface of the leaf, Isoetes and the Lycopodiales, with the exception of the Psilotaceæ, the exact relation of whose sporangia to the leaf is still in dispute, bear but one sporangium to a sporophyll, and that on the ventral surface at the base. Such exceptional forms as the Ophioglossaceæ and Marsiliaceæ do not help us in this inquiry. Though it may be true that the whole sporangiophore of the Ophioglossaceæ is, as several morphologists have suggested, the homologue of the single sporangium of Lycopodium or Isoetes, the suggestion is so hypothetical in itself as to give no support to any view based upon it. It is only in the position of the sporangium that these families approach Isoetes; in other sporangial characters, such as number and development, they are like other ferns.

The relative age of the leaves, when the sporangial rudiments first make their appearance, is of considerable significance. In the Filicales, with the exception of the heterosporous forms, 
which being leptosporangiate cannot be closely related to Isoetes, the sporangia appear late in the history of the leaf. There is an enormous development of the midrib with its conductive tissues, and of the expanded pinnæ, before the sporangia are recognizable. Nothing is more striking, however, than the quickness with which in the Lycopodiales and Isoetes the rudiment of the sporangium follows the inception of the leaf, which when the sporangium first comes into view is no more than a mere papilla of undifferentiated tissue, without a sign of photosyntactic or conductive tissue.

Still more far-reaching is the agreement of Isoetes with the Lycopodiales in the character of the sporangium rudiment. Goebel. ( I ) in his celebrated paper of I880-I classified sporangia as leptosporangiate or eusporangiate according as they arise from single cells or from groups of cells. Though the two classes are connected by transitional forms, such for instance as the Osmundaceæ, in which the sporangia, though always classified as leptosporangiate, do not arise strictly from single cells, the distinction has been approved by all later morphologists. The leptosporangiate plants make a well-defined and consistent group, but the eusporangiates comprise very diverse forms, including the several divisions of seed-plants, the Lycopodiales, the Equisetales, and part of the Filicales. If, however, we leave out accessories, and turn our attention entirely to the essential part of the sporangium, that is to the sporogenous tissue, we find a distinction which has the merit of leaving the Filicales an unbroken group, and of agreeing closely with what is required by a consideration of other characters. This distinction pertains to the origin of the archesporium. The spore-forming part of the sporangium of Isoetes and Lycopodiales can be traced back to a number of cells placed transversely to the leaf, but of all other pteridophytes to a single cell. Is not this distinction as valid as that which pertains to the origin of the whole sporangium? If so, it tends strongly to justify the inclusion of the Lycopodiales and Isoetes within a distinct group set apart from all other vascular cryptogams. 
Certain other features of the sporangium of Isoetes find duplication only among members of the Lycopodiales. In all the higher leptosporangiate ferns there is an elaborate mechanism for the bursting of the sporangium and the scattering of the spores. This device, consisting of a row of peculiarly thickened cells (the annulus), and a group of cells which form an easy place of rupture (the stomium), is very rudimentary in the lower leptosporangiates (Osmundaceæ), and in the Ophioglossaceæ and Marattiaceæ, but it is not altogether absent. There is at least a predetermined line along which dehiscence shall take place. The elaboration of this dehiscence apparatus is one of the chief peculiarities of the higher leptosporangiates. When we turn to the Lycopodiales and Isoetes, however, we find positively no contrivance for dehiscence, and no vestige of an annulus or stomium. The sporangium wall is simple, and bursts by desiccation in Lycopodium and Selaginella, and by decay in Isoetes; and neither method can be regarded as a specialization.

Another analogy has been brought to light by Bower's discovery in Lepidostrobus of certain radiating strands or processes in the sporangium which are regarded by him as very probably of the nature of trabeculæ. Since the relationship of Lepidostrobus to Lycopodium can hardly be doubted, there is here a point of contact with this group of plants in a feature in which otherwise Isoetes stands alone.

Again, Selaginella and Isoetes agree very nearly in the manner of selection of the megaspore mother cells. The unselected mother cells do not divide at all, and all the spores resulting from the division of the fertile ones as a rule reach maturity. In heterosporous ferns all the mother cells divide into spores, of which but one becomes a megaspore. The contrast may be expressed in the statement that the megasporangium is differentiated in Isoetes and Selaginella before the tetrad division, but in heterosporous ferns not until after that division.

The persistence of the tapetum in Lycopodiales and Isoetes is a character to which no great importance is to be attached, for 
tapetal characters are notoriously variable. Such bearing as it has, however, is in harmony with what may be inferred from other features of the sporangium. It involves no disorganization of the cells, no multiplication of nuclei except as related to celldivision, and no mingling of naked protoplasm with the young spores.

One of the facts which Vines advanced as an argument against the usually accepted classification of Isoetes is the absence of a strobilus, the characteristic arrangement of the sporophylls in the Lycopodiales. He contrasts also the elongated, slender, branched stem of Lycopodium or Selaginella with the short unbranched stem of Isoetes, which much more closely resembles that of some eusporangiate ferns. It may be doubted whether such superficial characters, unless accompanied by internal features of which they are the outward expression, have any value in settling the relationship of distinct genera or families. At all events, their usefulness in angiosperm taxonomy is limited to the distinction of species ; they would be of no use in deciding the family to which an undetermined species ought to belong. I am inclined to think the whole plant-body of Isoetes can best be explained as a shortened strobilus, just such as Lycopodium would become by suppression of the stem and axis, while allowing a normal development of the leaves and sporangia.

The most obvious diagnostic character of the three groups of pteridophytes is furnished by the leaves. The leaves of the Isoetes are sui generis, and afford little ground for associating it with any one group rather than another. Though they are relatively few and large, as is the case among ferns, their unbranched outlines and simple tissues show an analogy with the leaves of Lycopodiales; while their peculiar vascular bundles, and chambers, and diaphragms remove them as effectually from either group. There is record, it is true, of a fossil Isoetes with a branched leaf, indicating, when taken in conjunction with the sudden reduction of the vascular bundle just above the ligule, the possibility that the present form of the leaf may be a reduced one representing a more complex ancestral type. But 
we must admit, so far as mature leaf structures are concerned, that Isoetes occupies an isolated, and in no sense an intermediate position.

The testimony of the young leaves, however, is not so neutral. The form of the leaf rudiments, their manner of growth, and arrangement about the axes are the same in Isoetes as in Lycopodium and Selaginella, and quite different from what is seen among ferns. The difference is not fully expressed in saying that in one case the leaf originates from a single apical cell, and grows by means of it, and that in the other case the initiative is from a group of cells. The leaves of ferns are distinctly acrogenous, which method of growth gives them the power of assuming complex forms and allows the successive and often slow formation of stipe, pinnæ, and pinnules, and their gradual unfolding. A leaf which grows as does that of Isoetes has its power to assume a complex form limited to the time when it is meristematic throughout; as soon as the apex becomes permanent tissue the outline of the leaf is determined. The difference between such leaves is fundamental and far-reaching. A Lycopodium leaf could easily attain the size of an Isoetes leaf by retaining the meristematic power for a longer time, for they differ only in degree. The leaf of a fern could become like that of Isoetes, or vice versa, only by a radical change in the manner of growth.

The similarity of the leaf rudiments of Lycopodium and Isoetes is only a particular instance of a general likeness which extends to all their embryonic organs. We have already seen how this is true of the sporangia; and it holds equally good for the roots ${ }^{x}$ and stem apex. In none of these organs is there ever an apical cell or any concentric segmentation of the apices, such as are characteristic of all the Filicales and Equisetum. A difference in this respect in the case of apical-growing organs, like the roots and stem, may not lead to important differences in the mature structures, as the variation in the stem apices of Selaginella suffices to show. But a comparative examination of

${ }^{\mathrm{I}}$ Van Tieghem (I), but Bruchmann (I) entertains a different view. 
meristems was shown by Bower to possess considerable phylogenetic value, in the case of ferns, and to lead to results which agree with those arrived at by a comparison of other characters. The fact that Bower has since changed his view with regard to which type of fern is more primitive does not in any way lessen the value of his previous conclusions. If we extend the series made out by him it would be in this order : typical leptosporangiate ferns, Osmundaceæ, eusporangiate ferns, Selaginella, Isoetes, and Lycopodium. In this connection the dichotomy of the roots of Isoetes, Lycopodium, and Selaginella ought not to be overlooked.

The ligules of Selaginella and Isoetes were by Goebel made the ground for grouping the two genera into one order, the Ligulatæ, though the classification was recognized by its proposer as merely one of convenience. In the former part of this paper I have made a comparison of these organs, and expressed the view that their similarity is sufficient to demonstrate their homology. If this view is correct, it furnishes additional support to the relationship of Isoetes and the Lycopodiales, especially in consideration of the discovery of a ligule in the vegetative leaves and the sporophylls ${ }^{2}$ of Lepidostrobus, another lycopodiaceous plant.

Turning now to the gametophytes, we notice that when Vines suggested the connection of Isoetes and ferns, it was supposed that important differences existed between the female gametophytes of Isoetes and Selaginella; but the later and more complete investigations of Heinsen (I) and Arnoldi (I) have demonstrated their close resemblance. The diaphragm of the female gametophyte of Selaginella is not a true septum, and does not arise as Pfeffer (I) supposed it did, by the division of the spore into two cells. In both Isoetes and Selaginella, the free division of nuclei, their parietal placing, and the gradual extension of cell division from the periphery to the center of the spore are the same, and have no counterpart in the germination of the megaspores of heterosporous ferns. The gametophytes agree also in the absence of chlorophyll.

${ }^{2}$ Maslen (I). 
Nearly similar evidence is furnished by the male gametophyte. Though Belajeff (I), to whom we owe the most exact investigation of the subject, says the male gametophytes of Isoetes and Selaginella afford little ground for relating the two genera, he has shown several points of resemblance, such as the separation of the prothallial (or rhizoidal) cell from the single antheridium by a cellulose wall, and the final dissolution of the non-cellulose septa of the antheridium wall, so that the spermatozoids float free in the cavity of the spore.

Though not disposed to place much dependence as a clue to the working out of phylogenetic relationships among heterosporous plants on such structures as archegonia and antheridia, which must necessarily conform more or less in shape to the space in which they are confined, I find some interest in the fact that Isoetes and Lycopodium are the only genera of pteridophytes in which the occurrence of more than two neck canal nuclei has been reported, and that in Isoetes, as in Lycopodium Phlegmaria and Equisetum, the plane of the division of the primary neck canal nucleus is at right angles to the archegonium axis.

The two characters which stand most in opposition to the inclusion of Isoetes in the group Lycopodiales are its multiciliate spermatozoid and the embryogeny of its sporophyte. Campbell has very properly emphasized the similarity of the Isoetes spermatozoids to those of ferns. It requires only a brief survey of the plant kingdom to show the great constancy of the form and behavior of male cells in different classes of plants. Consider, for example, the non-motile spermatozoids of the Florideæ, or the biciliate spermatozoids of bryophytes. Accordingly, if we still classify Isoetes among Lycopodiales, we must admit that the multiciliate spermatozoids make an exception to a constancy which is otherwise remarkable. Unfortunately, we have only Lycopodium and Selaginella for comparison, and are still in ignorance as to what the gametophytes of the other genera may have to tell us.

The embryo of Isoetes finds its nearest approximation in Botrychium ${ }^{3}$ though the resemblance may be onty an external

${ }^{3}$ Jeffrey (I). 
one, due to the late differentiation of the embryonic organs and the suppression of the stem, rather than to any deep-seated likeness. However that may be, the sùspensor of Lycopodium and Selaginella is a positive morphological character separating them from Isoetes. Probably the embryos of Isoetes and Botrychium can be looked upon as generalized types, the specialization taking the form in ferns of a very early demarcation of the embryonic organs, and in Lycopodium and Selaginella of a suspensor.

Two other possible reasons for relating Isoetes to ferns deserve a passing mention. Of the connection between the velum and the indusium enough has already been said; and of the agreement of the stems of Isoetes and Botrychium it is sufficent to say that the agreement is simply in the fact of secondary thickening.

The claim that Isoetes is the genus of modern pteridophytes which makes the closest approach to angiosperms, particularly to monocotyledons, gives it an interest quite out of proportion to its numerical representation. It is not clear, however, that the claim is well supported by facts. Unquestionably Isoetes and Selaginella, in their heterospory, and their intrasporic and reduced gametophytes, exhibit features of life history which run closely parallel to that of seed-plants; but such features really foreshadow monocotyledons no more than they do other seed-plants. The hypodermal archesporium, and the origin of the megaspore mother cell as the lowest of a row resulting from periclinal divisions of an archesporial cell-two points which my observations disprove - would, if established, be as strong proof of a gymnosperm as of an angiosperm attachment. Some facts distinctly favor the gymnosperm connection; these are the manner of germination of the megaspore, and the method of selection of the megaspore out of a large mass of potentially sporeproducing cells, as in Cycas, Callitris, etc., to which may be added whatever favors the relationship of Isoetes with the Lycopodiales.

Professor Campbell has shown that the embryo of Isoetes bears a likeness to that of a monocotyledon in having a lateral 
stem apex and a terminal cotyledon, and suggests a comparison with the embryo of Alisma for instance. The resemblance in form is undoubtedly very close, but we ought not to overlook some equally important differences. The entire absence of a suspensor in Isoetes, which has been brought forward as an objection to its close affinity with Lycopodium, militates quite as strongly against an affinity with monocotyledons; and the foot, which is particularly well developed in Isoetes, cannot be said to have any clear representative in monocotyledon embryos.

In general habit Isoetes has been compared to some grasses, rushes, and the like; this is a mere external resemblance in one of the most adaptive features of plants, and not supported by internal and essential similarities. A similar objection can be raised to the comparison of the stelar regions of Isoetes and of such monocotyledons as Dracæna. In the latter it is true there is a secondary thickening carried on by means of an extra stelar "cambium," but this cambium merely adds parenchymatous tissue within which separate vascular bundles are organized; there is nothing strictly comparable to the prismatic zone or central xylem cylinder of Isoetes. Even were the likeness much closer than it is, the peculiar stem of Dracæna, Yucca, etc., is so certainly a newly acquired, and not a primitive character, that it affords no sound reason for deriving monocotyledons through an Isoetes-like type.

To one who has followed this discussion thus far it will be evident that in the writer's opinion the balance of evidence is in favor of relating Isoetes to Lycopodium and Selaginella rather than to eusporangiate ferns. Of course the facts are not all in hand as yet, and new discoveries may materially affect the aspect of the case. The facts which the present investigations have brought to light certainly tend in the one direction. The mode of origin, development, position, and general characters of the sporangia, the development of the leaf, and the nature of the ligule point to the correctness of including Isoetes among the Lycopodiales; while the form of the-spermatozcids and 
embryo show the necessity of making it a separate family. The Lycopodiales so constituted comprise six genera pretty widely separated in morphological characters, as from the antiquity of the group one might naturally expect. But the extreme differences are not greater than in the Filicales. If we can include Azolla, Marsilia, the common ferns, Hymenophyllum, the Marattiaceæ, and the Ophioglossaceæ in one group, it ought not to appear inconsistent to include Psilotum, Lycopodium, Phylloglossum, Selaginella, and Isoetes in a group of coordinate rank. A fuller knowledge of the three little-known genera may tend to confirm this view, especially if they depart as widely from the remaining genera in other characters as in general habit and sporangia; but if their gametophytes, spermatozoids, and embryos agree very nearly with Lycopodium and Selaginella, it will probably be better to make of Isoetes a fourth group of pteridophytes equivalent in rank to the three now universally recognized. If an affinity with seed plants must be sought, the evidence points to a connection with gymnosperms rather than with monocotyledons.

\section{SUMMARY.}

I. The stem apex lies at the bottom of a funnel-shaped depression, around the sides of which the leaves are arranged spirally. This depression is produced by the expansion of the cortical cells of the stem in all directions.

2. The leaves arise as crescent-shaped bands of meristematic tissue. At first the basal part of the leaf (the sheath) grows most rapidly; afterwards the region of growth is transferred to the part above the ligule. There is no persistent or sharplymarked zone of meristem. The whole leaf is meristematic at first; it then gradually passes into permanent tissue, the change beginning at the apex and extending gradually downwards.

3. The air-cavities are formed out of four longitudinal bands of cells, which after losing their contents and power of multiplication are ruptured into transverse partitions by the growth of the other parts of the leaf. The size, but not the number of the air-cavities, increases with the age and growth of the leaf. 
4. The ligule originates in a single vesicular cell as described by Hofmeister. The mature ligule can be distinguished into four regions: (I) the sheath which has its origin in the lowermost cells of the young ligule, (2) the glossopodium, (3) a region of living cells, and (4) a region of disintegrating cells.

5. The rudiment of the sporangium is a transverse row of superficial cells below the ligule; the upper part of this gives rise to the velum, the lower part to the sporangium proper.

6. There is no definite hypodermal archesporium. The middle cells of the sporangium Anlage are the first to undergo periclinal divisions. Additions to the sporogenous complex are made from the superficial cells of the sporangium.

7. The general direction of growth of the sporangium is at right angles to the face of the leaf, with a slight tendency in young sporangia to an upward direction. The cells are not in well-arranged rows or stratified layers.

8. There is no evidence that certain of the archesporial cells give rise to trabeculæ only, and certain others to mother cells only. The trabeculæ and megaspore mother cells or groups of microspore mother cells greatly outnumber the archesporial cells.

9. There is no evidence that each of the primary cells of the sporangium pursues an independent growth. On the contrary, their derivatives blend indistinguishably.

I0. The microsprangia and megasporangia are indistinguishable until they have attained a volume of $15,000-25,000$ cells.

II. The sporangium becomes recognizable as a microsporangium by its differentiation into irregular deeply-staining and feebly-staining radial bands. The deeply-staining regions after a period of active multiplication become the mother cells. The feebly-staining regions become the trabeculæ, walls, and tapetum,

I2. The tapetum is organized out of the layer of sterile cells adjacent to the mother cells; its cells are small, densely cytoplasmic, and persistent.

I3. The middle cells of the trabeculæ become elongated by compression and growth; their nuclei also become elongated and spindle-shaped. 
I4. The outer wall of the microsporangium is usually four layers thick, the innermost layer being part of the tapetum. The inner wall, that is the cells between the base of the sporangium and the vascular bundle, is probably formed by sterilization of cells derived from the primary cells of the sporangium.

I5. The divisions of the microspore mother cells may be either successive or simultaneous. The two spindles of the second division do not become connected by secondary fibers. The microspores are usually bilateral but sometimes tetrahedral.

I6. The number of microspores in a sporangium is $150,000-$ 300,000 .

17. A sporangium first becomes recognizable as a megasporangium by the marked enlargement of many or most of the cells of about the third and fourth layers. All such enlarged cells are to be regarded as potential mother cells, and the number of them which succeed in producing megaspores is probably dependent on nutrition. No tabular tapetal cells are cut off in connection with the development of the megaspore mother cells, nor is the megaspore mother cell the innermost of a row of cells formed from a single archesporial cell in a manner comparable to what is seen in the ovules of seed-plants.

I8. Many cells which enlarge almost to the size of mature mother cells are finally unable to give rise to spores, but divide up into smaller cells which ultimately form part of the tapetum.

19. The trabeculæ, tapetum, and walls arise in the megasporangium as in the microsporangium, the chief difference being the greater massiveness of the single trabeculæ in the former and the much greater abundance of the tapetum.

20. No details of the division of the megaspore mother cell were obtainable. The megaspores are usually tetrahedral in arrangement, but occasionally bilateral. The number in a sporangium is $150-300$.

2I. The first leaves of a season are megasporophylls, and these are succeded by microsporophylls. There is occasionally some irregularity in the order of succession, and sometimes a sporangium is found which bears both kinds of spores. 
22. The sterile leaves in a majority of cases have aborted sporangia. When these have made any considerable development they are usually found to show the characters of megasporangia.

23. The sporangia after all cell divisions have ceased continue to increase in volume, apparently by the osmotic properties of the substances surrounding the young spores.

24. An attempt to relate the change from megasporophylls to microsporophylls to an exhaustion of the nutritive cortical cells formed in the preceding year was unsuccessful.

25. To secure a more consistent nomenclature it is proposed to employ the term archesporium in speaking of a pteridophyte sporangium to designate the superficial cell or cells from which the sporogenous tissue takes its origin.

I am indebted to Professor John M. Coulter, of the University of Chicago, at whose suggestion the investigation was undertaken, for helpful suggestions and criticisms. Acknowledgments are also due to Dr. C. J. Chamberlain.

McMaster University,

Toronto, Canada.

\section{BIBLIOGRAPHY.}

ARNoldi, W. (I) Die Entwickelung des weiblichen Vorkeimes bei den heterosporen Lycopodiaceen. Bot Zeit. 54 : I 59-168. 1896.

BelajefF, W. (I) Die Antheridien und Spermatozoiden der heterosporen Lycopodiaceen. Bot. Zeit. 43:793-802, 809-8 I 9. I 885 .

(2) Ueber Bau und Entwickelung der Spermatozoiden der Gefässkryptogamen. Ber. der deut. bot. Gesell. 7 : 12 I-I25. I889.

(3) Ueber Bau und Entwickelung der Spermatozoiden der Pflanzen. Flora $79:$ I -48 . I 894 .

(4) Ueber die männlichen Prothallien der Wasserfarne (Hydropterides). Bot. Zeit. 56 : 14 I-I94. I 898 .

Bower, F. O. (I) Comparative morphology of the leaf in the vascular cryptogams and gymnosperms. Phil. Trans. Roy. Soc. I75:565-6I5. 1884.

(2) The comparative examination of the meristem of ferns as a phylogenetic study. Ann. Bot. 3:305-392. 1889 .

(3) Is the eusporangiate or the leptosporangiate the more primitive type of fern? Ann. Bot. 5: 109-134. I891. 
(4) Studies in the morphology of spore-producing members: Equisetineæ and Lycopodineæ. Phil. Trans. Roy. Soc. B. 185:478-572. 1894 .

(5) Studies in the morphology of spore-producing members: Ophioglossaceæ. Proc. Roy. Soc. 59 : I37-I41. I896.

(6) Studies in the morphology of spore-producing members: Marattiaceæ. Phil. Trans. Roy. Soc. B. I89:35-81. I897.

(7) Studies in the morphology of spore-producing members: Leptosporangiate Ferns. Phil. Trans. Roy. Soc. B. 192:29-138. I899.

Bruchmann, H. (I) Ueber Anlage und Verzweigung der Wurzeln von Isoetes und Lycopodium. Jenaische Zeitschrift für Naturwissenschaften. 1874 .

Campbell, D. H. (I) The development of Pilularia globulifera. Ann. Bot. 2 :233-264. I 888.

(2) The systematic postion of the Rhizocarpeæ. Bull. Torr. Bot. Club I5 : 258-262. I 888 .

(3) On the affinities of the Filicineæ. Bot. Gaz. 15: I-7. I 890.

(4) Contributions to the life history of Isoetes. Ann. Bot. $5: 23$ I -258. I89I.

(5) On the relationships of the Archegoniatæ. Bot. Gaz. r6:323-333. I $89 \mathrm{I}$.

(6) On the development of Azolla filiculoides. Ann. Bot. $7:$ I55-187. I 893 .

(7) Observations on the development of Marattia Douglasii. Ann. Bot. 8 : I-20. I 894 .

(8) The structure and development of mosses and ferns. Macmillan Co. 1895 .

DEBARy, A. (I) Comparative anatomy of the vegetative organs of the phanerogams and ferns. Oxford, I884.

FARMer, J. B. (I) On Isoetes lacustris. Ann. Bot. 5:37-62. I 890.

(2) The embryogeny of Angiopteris evecta. Ann. Bot. 6:265-270. 1892 .

Gibson, Harvey. Contributions toward a knowledge of the anatomy of the genus Selaginella.

(I) The stem. Ann. Bot. $8:$ I3 I-206. I894.

(2) The ligule. Ann. Bot. 10:77-88. 1896.

(3) The leaf. Ann. Bot. Ir: 123-I55. I897.

Goebel, K. (I). Beitrage zur vergleichenden Entwickelungsgeschichte der Sporangien. Bot. Zeit. $38: 545-552,56 \mathrm{I}-572$. I880, and $39: 68 \mathrm{I}-694$, 697-706, 71 3-720. I881.

(2) Vergleichende Entwickelungsgeschichte der Pflanzenorgane. Schenk's Handbuch der Botanik 3:- I 884.

(3) Outlines of classification and special morphology. Oxford, 1887. 
Hegelmaier, F. (i) Zur Morphologie der Gattung Lycopodium. Bot. Zeit. 30: 773-779, 789-80 I, 805-8 I 9, 82 I-833, 837-851. I872.

Heinsen, E. ( I) Die Makrosporen und weiblichen Prothallium von Selaginella. Flora $78: 466-496$. I 894 .

Hofmeister, W. (I) The higher cryptogamia. Ray Soc. London. I862.

Holtzman, C. L. (I) On the apical growth of the stem and the development of the sporangium of Botrychium Virginianum. Bot. Gaz. 17:214217. I 892 .

JanCzewsKi, ED. (I) Vergleichende Untersuchungen ueber die Entwickelungsgeschichte des Archegoniums. Bot. Zeit. 30:377-393, 40I-420, 440-448. I 872.

Jeffrey, E. C. (I) The gametophyte of Botrychium Virginianum. Trans. Canadian Institute. $1896-7$.

(2) The development, structure, and affinities of the genus Equisetum. Memoirs Boston Soc. Nat. Hist. I 899 .

Johnson, D. S. (I) On the development of the leaf and sporocarp in Marsilia quadrifolia. Ann. Bot. I2 : I I9-145. 1898.

(2) On the leaf and sporocarp of Pilularia. Bot. Gaz. $26:$ I-24. I898.

Kienitz-Gerloff, F. (I). Ueber Wachsthum und Zelltheilung in der Entwickelung des Embryos von Isoetes lacustris. Bot. Zeit. 39:76I-770. I 88 I.

Maslen, A. J. (I) The ligule in Lepidostrobus. Ann. Bot. 12:256-259. I 898.

Millardet, A. (I) Le prothallium mâle des cryptogames vasculaires. Strasburg, I 869 .

Pffffer, W. (I) Die Entwickelung des Keimes der Gattung Selaginella. Hanstein's Abhandl. 4:--. I87 I.

PoIrault, G. (I) Recherches anatomiques sur les cryptogames vasculaires. Ann. Sci. Nat. Bot. VII. 18 : I I 3-256. I894.

Russow, E. (I) Vergleichende Untersuchungen betreffend der LeitbündelKryptogamen. Mém. de l'Acad. Imp. des Sciences de St. Petersburg VII. I9:- 1872 .

SADEBECK, R. (I) Die Gefässkryptogamen. Schenk's Handbuch r:I 882.

Strasburger, E. (I) Einige Bemerkungen ueber Lycopodiaceen. Bot. Zeit. 3I : 8I-93, 97-I I I, I I 3-I I9. I 873 .

(2) Zellbildung und Zelltheilung. I 886.

(3) Zur Kenntniss einiger Lycopodinen. Bot. Zeit. $32: 481-488,497-$ 505, 513-524. I874.

TReub, M. (I) Études sur les Lycopodiacées. Ann. Jard: bot. Buit. 4 : I884 ; 5: $1886 ; 7:$ I $888 ; 8:$ I 889 .

Tschistiakoff. (I) Notice sur le développement des sporanges de l'Isoetes Durieui. Nuovo Giornale bot. Ital. 1873 . 
Van Tieghem, Ph. (I) (et Duliot) Recherches comparatives sur l'origine des membres endogènes dans les plantes vasculaires. Ann. Sci. Nat. Bot. VIII. 8 : I-656. I 888 .

(2) Traite de Botanique. I89 I.

-Vines, S. H. (I) The systematic position of Isoetes. Ann. Bot. 2: 117-I23, 223-224. 1888-9.

(2). A text-book of botany. I895.

\section{EXPLANATION OF PLATES XIII-XX.}

The drawings, except fig. I, have been made with the aid of a camera lucida, and all have been reduced by photography to two fifths of their original size. Both in the text and in the explanation of the plates, the terms transverse, longitudinal, and tangential, when used to describe sections of the ligule and the sporangium are to be understood as indicating the planes in which the sporophylls were sectioned.

FIG. I. Base of microsporophyll, inner face showing the sporangium $(s)$, the velum $(v)$, and the ligule $(l) . \times 4$.

FIG. 2. Radial longitudinal section of base of sporophyll; $s, v, l$, as in fig. I. $\times 5$.

FIG. 3. Longitudinal section of apex of a small plant. $\times 48$.

FIG. 4. Longitudinal section of apex of a larger plant; $x$, the tracheids, $p$, the prismatic layer, $t$, the leaf traces, $m$, the cambium (semidiagrammatic). $\times 48$.

FIG. 5. Part of the prismatic ring as seen in transverse section of the stem ; $x, p, t, m$, as in fig. $4 . \times \mathrm{I} 60$.

FIG. 6. Cortical cells from the neighborhood of the cambium. $\times 240$.

FIG. 7. Cortical cells from the outer region of stem. $\times 240$.

FIG. 8. Longitudinal section of a number of young sporophylls; the sporangia are indicated by the dotted outlines. $\times 48$.

FIG. 9. Cross section of a young leaf above the ligule. $\times 300$.

FIG. Io. Cross section of a young leaf more advanced than that shown in fig. 9; the position of the future air chambers is shown by the groups of nearly empty cells; the small circles of figs. $g$ and $I O$ indicate the side towards the axis of the plant. $\times 300$.

FIG. I I. Part of a longitudinal section of a leaf more advanced than that of $f i g$. 10 , showing origin of the air cavities; $p$, the phloem, $x$, the xylem. $\times 300$.

FIGS. I2-I3. Transverse section of leaf with the vesicular cell from which the ligule originates. $\times 300$.

FIG. I4. First division of the ligule, sectioned in plane $a-a$ of $f g .15$. $\times 490$.

FIG! 15. First division of the ligule seen in radial longitudinal section. $\times 490$. 
Figs. 16, I8. First division of terminal cell of ligule sectioned in plane $a-a$ of fig. 15. $\times 490$.

FIG. I7. The same sectioned in plane $b-b$ of $f i g .15 . \times 490$.

FIG. I9. Tangential section of older ligule. $\times 490$.

FIG. 20. Transverse section of ligule of same age as that of fig. Ig. $\times 490$.

F千G. 2I. Transverse section of still older ligule. $\times 300$.

FIG. 22. Median radial longitudinal section of base of half-grown ligule; $s$, the sheath, $g$, the glossopodium, $v$, the velum. $\times 490$.

FIG. 23. Radial longitudinal section of base of mature ligule at the position indicated by $a-b$ of $f i g$. 25, showing the thickened cells of the velum and leaf adjacent to the ligule. $\times 48$.

FIG. 24. The same in I. Engelmanni. $\times 48$.

FIG. 25. Transverse section of ligule and leaf at the position indicated by $a-b$ of $f i g .23 . \times 30$.

FIG. 26. Median radial longitudinal section of young sporophyll, showing rudiment of the sporangium. $\times 490$.

FIGs. 27-28. The same more advanced. $\times 490$.

FIG. 29. Transverse section of young sporophyll with sporangium. $\times 490$.

FIG. 30. Transverse section of sporangium more advanced. $\times 490$.

FIG. 3I. Tangential section of young sporangium. $\times 490$.

FIGs. $32-38$. Radial longitudinal sections of young sporophyll; fig. 37 is a section through the side of the sporangium of which $f \mathrm{~g} .36$ is a median section; $v$, the velum, $g$, the glossopodium, $s$, the sheath. $\times 490$.

FIG. 39. Transverse section of sporangium more advanced. $\times 490$.

FIG. 40. Transverse section of leaf with sporangium of same age as that of $\mathrm{fig} .39 . \times 490$.

FIG. 4I. Median radial longitudinal section of a sporangium of about the same age as the last. $\times 490$.

FIG. 42. Longitudinal section of side of sporangium. $\times 490$.

FIG. 43. Transverse section of a sporangium still older but in which the trabeculæ are not yet recognizable. $\times 490$.

FIG. 44. Transverse section of young leaves and of microsporangium at the time of the first differentiation of fertile and sterile regions; the shaded portion represents the fertile region; $v$, the velum, $l$, the ligule, $f$, the vascular bundle. $\times 48$.

FIG. 45. Oblique nearly tangential section of microsporangium. $\times 48$.

FIG. 46. Tangential section of microsporangium. $\times 30$.

FIG. 47. Cross section of sporophyll and microsporangium, showing the trabeculæ, tapetum, $t$, and a few microspores; $v$, the velum (semidiagrammatic). $\times 30$.

FIG. 48. Portion of microsporangium at the time of the first differentiation of fertile and sterile regions. $\times 490$. 
FIG. 49. The same, showing portion of outer wall. $\times 490$.

FIG. 50. Portion of an older microsporangium, showing differentiation of sterile regions into trabeculæ and tapetum $(t) . \times 490$.

FIG. 5I. Portion of trabecula, tapetum $(t)$, and young spores of a microsporangium. $\times 490$.

FIG. 52. Part of outer wall and tapetum $(t)$ of nearly mature microsporangium. $\times 490$.

FIGS. 53-55. Division of mother cells to form microspores; fig. 53 illustrates successive division; fig. 54, simultaneous division; fig. 55, the shape of the spores, bilateral in $a$ and $b$, tetrahedral in $c$. $\times 490$.

FIG. 56. Young microspores. $\times 490$.

FIG. 57. Cross section of megasporangium with young spores and tapetum $(t) . \times 48$.

FIG. 58. Portion of a trabecula and tapetum $(t)$ of a megasporangium, $\times 490$.

FIG. 59. Tetrahedral arrangement of young megaspores. $\times 490$.

Figs. 60-6r. Successive division of megaspore mother cells, spores bilateral. $\times 490$.

FIG. 62. Median radial longitudinal section of sterile leaf with aborted sporangium (shaded).

FIG. 63. Transverse section of megasporangium first distinguishable as such. $\times 490$.

FIG. 64. Part of transverse section of a megasporangium with a group of potential mother cells. $\times 490$.

FIG. 65. The same with a single mother cell. $\times 490$.

FIG. 66. Part of a transverse section of a megasporangium; for explanation see text. $\times 490$.

FIG. 67. Diagram of young megasporangium.

FIG. 68. Diagram of a longitudinal section of the stem. See p. 228.

FIGS. 69, 70. Early stages of the sporangium of a fern. Diagrammatic. $a$, archesporium ; $f$, fertile sporogenous cell ; $s$, sterile wall cell.

FIGS. 71, 72. Early stages of a microsporangium of an angiosperm. Diagrammatic. $a$, archesporium ; $e$, epidermis ; $s$, primary tapetum ; $f$, primary sporogenous cell or cells.

FIGS. 73, 74. Early stages of a megasporangium of an angiosperm. Diagrammatic. Letters as in figs. 71,72 . 


\section{$2 \mathrm{BHL}$ Biodiversity Heritage Library}

Smith, R Wilson. 1900. "The Structure and Development of the Sporophylls and Sporangia of Isoetes (Concluded)." Botanical gazette 29(5), 323-346. https://doi.org/10.1086/327991.

View This Item Online: https://www.biodiversitylibrary.org/item/95198

DOI: https://doi.org/10.1086/327991

Permalink: https://www.biodiversitylibrary.org/partpdf/223053

\section{Holding Institution}

Missouri Botanical Garden, Peter H. Raven Library

\section{Sponsored by}

Missouri Botanical Garden

\section{Copyright \& Reuse}

Copyright Status: Public domain. The BHL considers that this work is no longer under copyright protection.

This document was created from content at the Biodiversity Heritage Library, the world's largest open access digital library for biodiversity literature and archives. Visit BHL at https://www.biodiversitylibrary.org. 